\title{
Examining Students' Attitudes towards Using Tablets Outside School Contexts
}

\author{
Tugba Mutlu
}

\begin{abstract}
This paper reflects on a research that was carried out in Turkish secondary schools where tablets were supplied to students across the country by the government. There is a growing number of research trying to explain students' attitudes towards using tablets for in-school activities, however, the literature is very limited in showing students' attitudes to using tablets outside the school and the pattern of usage. As 'mobility' is the main attribute of mobile learning, it is equally important to understand the use pattern outside the school context. This paper will examine and explain how and why the tablets were / were not used by the students in their free times while comparing the use pattern with that of computers and smart phones. Data was gathered through questionnaires and student focus groups. Results show that, contrary to our expectations, students do not use their tablets in their free times and smart phones are still the first choice of mobile while computers remain to be the main tool for school works.
\end{abstract}

Index Terms-Mobile learning, student attitude, tablet, use pattern.

\section{INTRODUCTION}

With the increasing demand to mobility and connectedness anywhere at any given time, mobile devices have become indispensable parts of our daily lives. People are expected to survive in the digital world; capable of searching, understanding, evaluating and analyzing information from different sources in different formats as well as adding information. Thus, it has become a necessity for education institutions and governments to provide ICTs and teach the skills associated with the use of these devices.

As Dorman [1] states;

Education (...), competition (...), the workplace, jobs and skill demands are changing. These changes, among others, are ushering us toward a world where knowledge, power, and productive capability will be more dispersed than at any time in our history-a world where value creation will be fast, fluid, and persistently disruptive. A world where only the connected will survive.

In order to keep up with the ever changing demands of job market and prepare new generations for the requirements of fast moving digital world, policy makers have started reviewing the existing policies and many countries have run at least a pilot program with mobile devices of some sort.

Teaching and learning with technology has a long history. Education has seen many technology integration attempts from computers to overhead projectors, clickers to PDAs, and

Manuscript received July 10, 2015; revised January 12, 2016. This work was supported by the Turkish Ministry of National Education.

Tugba Mutlu is with the University of Sheffield School of Education, UK (e-mail: tmutlu1@sheffield.ac.uk). lately tablets have started to claim their places in classrooms (Perez, Gonzalez, Pitcher \& Golding [2]).

Since their arrival, tablets have been seen to be the strongest candidate to cure long- lasting problems that traditional education systems cause by transforming teachers' role from being the "sage on the stage" to the "guide on the side" (Van Dusen [3], 2000 as cited in Tamim, Borokhovski, Pickup \& Benard [4]) and this is mainly due to tablets' versatile nature. Tablets are capable of performing every tasks that their predecessors perform while being portable, mobile, always connected; supporting individual, adaptive and personalized learning; allowing student centered, collaborative and interactive learning (Melhuis \& Falloon [5]). These unique features have led policy makers and researchers to believe that tablets could have potential to improve learning, and provide digital literacy skills required by today's world.

Countries such as UK, Australia, Thailand, Brazil, Malta, Turkey, Russia, some South African countries, United Arab Emirates and many other countries have invested in tablets at different scales [5]. Even though there have been references of success; many of these initiatives do not always have the desired results. In their research, Perez et al. [2] found that even though students have positive attitudes towards using tablets for their coursework, there was not significant improvement in the final outcome of student learning. And after reviewing the latest research, Nguyen, Barton \& Nguyen [6] concluded that impact of tablets are still not known due to mixed results coming from research. Therefore, more research needed on the tablets effectiveness in education.

Turkey, where this research was conducted, have been running a large scale countrywide tablet deployment program called "Movement of Enhancing Opportunities and Improving Technology", otherwise known as the Fatih Project, in which every student and teacher receives a tablet. The project aimed at transforming the education by creating 'smart classrooms' equipped with LCD Interactive boards, Wi-Fi network and tablets. The tablets provided within the scope of this project are Android devices. There have been three different suppliers Samsung, Vestel and General Mobile. This paper's focus is on the specific mobile learning case of Turkey.

According to Kinash, Brand and Mathew [7], mobile learning refers to a wider concept; making possible to move "within, beyond and between" the space, content and context. As Traxler [8] states:

Interacting with a desktop computer takes place in a bubble, and in dedicated times and places where the user has his or her back to the rest of the world for a substantial and probably premeditated episode. Interacting with mobile technologies is 
different and is woven into all the times and places of students' lives. Desktop technologies and landline phones are about buildings; mobile devices are about people.

As Traxler [8] suggests, tablets cannot be expected to be used only in fixed places or times. They are meant to create spaces between spaces, where students can learn any time in any context with/from anybody. Research on learning with tablets in the space of school is growing every day, while, to our knowledge, use of these devices outside the school remains under researched. This presents a challenge, as currently there is not enough research exists on tablets' use outside the school context. Therefore, this research explores how student do or do not use their tablets when they are not in school, which is important to develop a roadmap for the future of learning with tablets, and mobile learning in general.

\section{DATA PRESENTATION}

\section{A. Participants and Methods}

This research was conducted in three different secondary schools which were at the time participating in the pilot phase of the project. All three of them are public schools with very different student profiles. One of them is known to be one of the most successful public schools in the country, accepting students with very high scores from the entrance examination while the second school could be considered as decent, and the third school is not as successful as the other two. Therefore, the bias from student profiles was eliminated.

As the Fatih Project runs in different phases, students receive their tablets in different times. In order to avoid the initial excitement of owning a tablet, only the students who had owned the tablets at least for 6 months were included in the survey. Therefore, all of the participants were at least in their second year in secondary school.

Questionnaires and focus groups are the main source of data as well as observations. 270 students participated in the study; 141 girls $(52.2 \%), 127$ boys (47\%) and 2 other $(0.7 \%)$. 266 questionnaires returned valid. Later, 3 focus group sessions were held with the volunteered students.

\section{B. Results}

Questionnaire and focus group data were analyzed, and the analysis showed that they complement each other.

First, students were asked whether they had a personal tablet, a computer (laptop+desktop). We wanted to know if previously owning a tablet has any effect on the use pattern. Below, the Fig. 1 and Fig. 2 show that around 20\% of the students owned a tablet before receiving one from their schools whereas $98.9 \%$ said they had computers before receiving a tablet (Fig. 2). This shows that computers are still the primary computing devices among students.

TABLE I: PREVIOUS TABLET OWNERSHIP

\begin{tabular}{|ll|l|l|l|l|}
\hline & Frequency & Percent & Valid Percent & Cumulative Percent \\
\hline \multirow{4}{*}{ Valid } & No & 208 & 78.2 & 78.2 & 78.2 \\
& Yes & 58 & 21.8 & 21.8 & 100.0 \\
& Total & 266 & 100.0 & 100.0 & \\
\hline
\end{tabular}

TABLE II: PREVIOUS COMPUTER OWNERSHIP

\begin{tabular}{|ll|l|l|l|l|}
\hline & & Frequency & Percent & Valid Percent & Cumulative Percent \\
\hline \multirow{4}{*}{ Valid } & No & 3 & 1.1 & 1.1 & 1.1 \\
& Yes & 263 & 98.9 & 98.9 & 100.0 \\
& Total & 266 & 100.0 & 100.0 & \\
\hline
\end{tabular}

TABLE III: AVERAGE DAILY TABLET USE AFTER SCHOOL

\begin{tabular}{|l|l|l|l|l|}
\hline & Frequency & Percent & Valid Percent & Cumulative Percent \\
\hline Never & 131 & 49.2 & 49.2 & 49.2 \\
1 to 3 hours & 65 & 24.4 & 24.4 & 73.7 \\
Less than 1 hour & 52 & 19.5 & 19.5 & 93.2 \\
3 to 5 hours & 9 & 3.4 & 3.4 & 96.6 \\
No answer & 5 & 1.9 & 1.9 & 98.5 \\
More than 5 hours & 4 & 1.5 & 1.5 & 100.0 \\
Total & 266 & 100.0 & 100.0 & \\
\hline
\end{tabular}

Fig. 3 below shows the average daily tablet use after school. Surprisingly, $49.2 \%$ of the students reported no use, around $20 \%$ reported only less than an hour of use, $24.4 \%$ reported 1 to 3 hours of usage on average daily while reporting higher computer use (Fig. 4).
In the research conducted with college students and undergraduate students, respectively, Poll [9] and Dahlstrom, Bichsel [10] have concluded that ownership and use rate of computers are still higher than that of tablets. As our results also indicate a similar trend, this shows that the tendency in 
choosing computing devices among students is similar even at different age and levels of education. Considering the fact that tablets are still new compared to computers, higher computer ownership is no surprise. However knowing that $80 \%$ of the students did not have a personal tablet previously, use for longer hours was expected. However, data shows that nearly half of the students reported no use at all outside the school, including non-school activities. This is surprising, however; previous research show this could happen due to the novelty effect which leads to higher usage and improved results for a while until the initial excitement wears off (Bull [11]). But still the usage rate is very low and also the question "why do not students use their tablets for leisure activities, such as gaming, social media etc., which is very common among the given age group?" remains. In order to find answers focus groups were employed. Students reported higher rates of smartphone usage for the majority of their daily needs, and listed various technical and personal reasons.

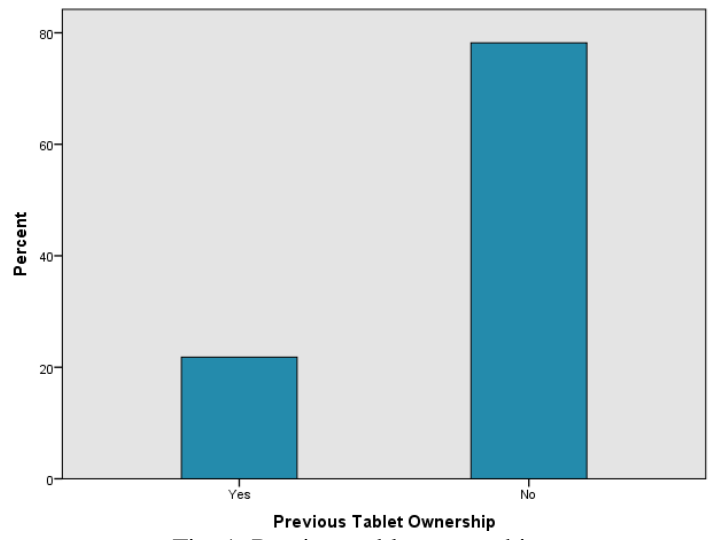

Fig. 1. Previous tablet ownership.

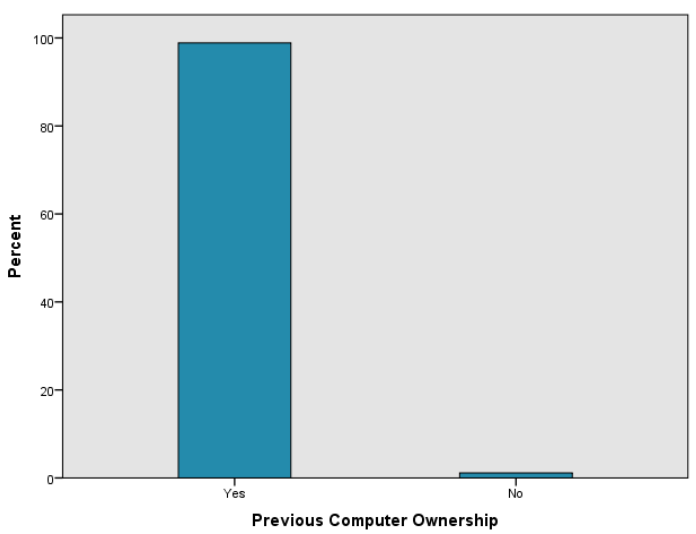

Fig. 2. Previous computer ownership.

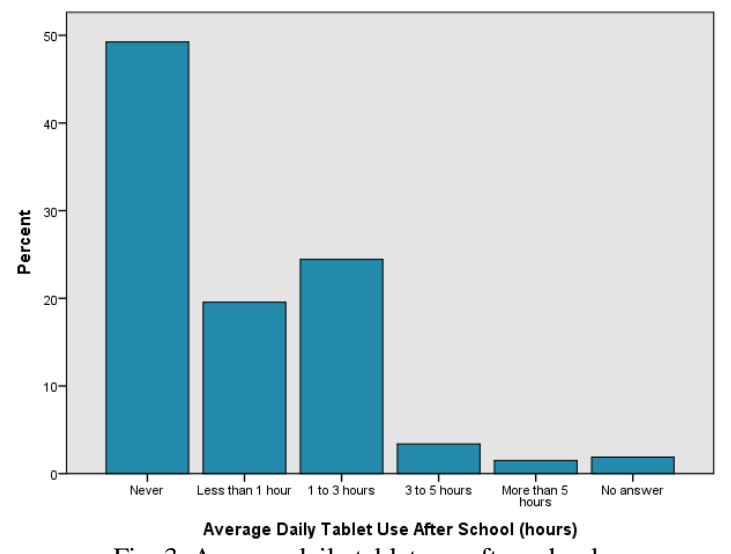

Fig. 3. Average daily tablet use after school.
TABLE IV: AVERAGE DAILY COMPUTER USE AFTER SCHOOL

\begin{tabular}{|l|l|l|l|l|}
\hline & Frequency & Percent & Valid & $\begin{array}{l}\text { Cumulativ } \\
\text { e Percent }\end{array}$ \\
\hline $\begin{array}{l}\text { 1 to 3 hours } \\
\text { Less than 1 hour }\end{array}$ & 160 & 60.2 & 60.2 & 60.2 \\
Never & 34 & 13.2 & 13.2 & 73.3 \\
3 to 5 hours & 19 & 12.8 & 12.8 & 86.1 \\
More than 5 hours & 14 & 5.3 & 7.1 & 93.2 \\
No answer & 4 & 1.5 & 1.5 & 100.0 \\
Total & 266 & 100.0 & 100.0 & \\
\hline
\end{tabular}

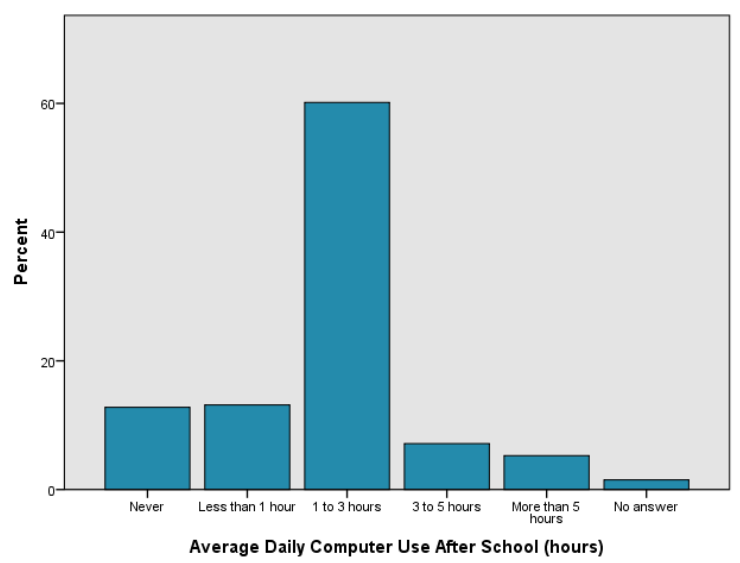

Fig. 4. Average daily computer use after school.

Focus groups revealed that computers are still the main tools for schoolwork due to high ownership rates and more convenient softwares such as Microsoft Office.

The main reasons behind low rates of tablet use are reported as lack of privacy and less portability. Students reported that no matter how personal it is, there is always a privacy breach from a family member as tablets are perceived as shared devices rather than personal. This concurs with the findings of Mascheroni and Olafsson [12] in the Net Children Go Mobile report. They state that children between 9 to 16 years old perceive tablets as 'shared devices' rather than personal and report higher smart phone usage than tablet usage on daily basis. Second, smart phones are considered more portable than tablets.

"I can carry my smart phone in my pocket but the tablet needs an extra hand"

Other reasons are frequent system errors or easy breakdowns and strict security filters imposed by the government. This suggests that students value quality and usability of their devices. As Viriyapong, Hartfield emphasize 'ensuring usability' is one of the main challenges preventing initiatives from succeeding [13].

"These tablets are just like tablet of pills, they break easily"

"They say some of the functions in tablets are blocked for security reasons but they made tablets completely useless"

Even though majority of the students reported no use, some students reported short amount of daily use. Because the 
government doesn't provide the printed text books anymore, only e-books pre-uploaded to tablets, students have to use their tablets in order to access books whenever they have homework, project or exam. Also, not having Internet connection or another computing device at home is another reason for them to use their tablets in public places to access online sources for their homework.

"Because I do not have a computer at home and there is not Internet connection, I use my tablet to search for online sources, and I do the homework at home"

\section{CONCLUSION}

Finally, this study was conducted in secondary schools to understand students' attitudes towards using tablets after school hours. The results are in line with the existing research. Even though smart phone preference over a tablet is a personal choice, it is investors' responsibility to make sure the devices provided are 'usable'. Therefore, there must be quality assessment criteria before the distribution of devices.

Even though the number of participants are not big enough to provide generalizable information, this research provided a valuable insight into the attitudes of the end users as well as the problems that need to be considered in order to create a healthy mobile learning space not only in school borders but also at home, or on the move. Future work could be conducted with more participants.

\section{REFERENCES}

[1] J. Dorman. (2007). Engaging digital natives: examining 21st century literacies and their implications for teaching in the digital age. [Online] Available: http://www.slideshare.net/cliotech/engaging-digital-natives

[2] O. A. Perez, V. Gonzalez, M. T. Pitcher, and P. Golding, "Work in progress: analysis of mobile technology impact on STEM based courses; specifically introduction to engineering in the era of the iPad," presented at the 118th ASEE Annual Conference and Exposition, Vancouver, BC: Canada, June 26-29, 2011.

[3] G. V. Dusen, "Digital dilemma: Issues of access, cost, and quality in media-enhanced and distance education," ASHE-ERIC Higher Education Report, vol. 27, no. 5, pp. 1-120, 2000.

[4] R. M. Tamim, E. Borokhovski, D. Pickup, and R. M. Bernard. (2015). Large-scale, Government-supported educational tablet initiatives. [Online]. Available: http://oasis.col.org/bitstream/handle/11599/809/COL\%20Tablet\%20I nitiatives.pdf?sequence $=1 \&$ is Allowed $=y$

[5] K. Melhuish and G. Falloon, "Looking to the future: M-learning with the iPad," Computers in New Zealand Schools: Learning, Leading, Technology, vol. 22, no. 3, pp. 1-16, 2010.

[6] L. Nguyen, S. M. Barton, and L. T.Nguyen, "iPads in higher education-Hype and hope," British Journal of Educational Technology, vol. 46, pp. 190-203, 2015
[7] S. Kinash, J. Brand, and T. Mathew, "Challenging mobile learning discourse through research: Student perception of blackboard mobile learn and iPads," Australasian Journal of Educational Technology, vol. 28 , pp. 639-655.

[8] J. Traxler, "Will student devices deliver innovation, inclusion and transformation?" Journal of the Research Centre for Educational Technologies, vol. 6, no. 1, pp. 3-15, 2010.

[9] H. Poll. (2014). Pearson Student Mobile Device Survey: College Student. [Online]. Available: http://www.google.co.uk/url?sa=t\&rct=j\&q=\&esrc=s\&source=web\&c $\mathrm{d}=2 \& v e d=0 \mathrm{CDcQFj} A B$ ahUKEwjoh93OqZ_HAhVIbxQKHcqiCSU\& url=http $\% 3 \mathrm{~A} \% 2 \mathrm{~F} \% 2 \mathrm{Fwww}$.pearsoned.com\%2Fwp-content $\% 2$ Fuploa ds\%2FPearson-HE-Student-Mobile-Device-Survey-PUBLIC-Report051614.pdf\&ei=mwXJVajOO8jeUcrFpqgC\&usg=AFQjCNFjVr6L3p XAdYP9-kshh56wpJWDmQ\&sig2=UjNzxF6nQAo13AEXjAz6Iw\&b vm=bv.99804247,d.d24

[10] E. Dahlstorm and J. Bichsel. (2014). ECAR study of undergraduate students and information technology, 2014. Research Report. [Online]. Available:

https://www.google.co.uk/url?sa=t\&rct=j\&q=\&esrc=s\&source=web\& $\mathrm{cd}=2 \&$ ved=0CDEQFjABahUKEwjloOD6qJ_HAhXJWhQKHfskBC w\&url=https $\% 3 \mathrm{~A} \% 2 \mathrm{~F} \% 2$ Fnet.educause.edu $\% 2$ Fir $\% 2$ Flibrary $\% 2$ Fpdf \%2Fss14\%2FERS1406.pdf\&ei=6wTJVaX_NMm1UfvJkOAC\&usg= AFQjCNEytO-kK-RDsbN-3YWNY5Hb61cBEg\&sig2=p7wuwaBKy 903u8NHWYsHYg\&bvm=bv.99804247,d.d24\&cad=rja

[11] B. Bull. (August 2013). Why some educational technology efforts decrease student learn in. [Online]. Available: http://blog.apastyle.org/apastyle/2010/11/how-to-cite-something-youfound-on-a-website-in-apa-style.html

[12] G. Mascheroni and K. Olafsson. (2013). Mobile internet access and use among European children. Initial findings of the Net Children Go Mobile project. [Online]. Available: http://www.google.co.uk/url?sa=t\&rct=j\&q=\&esrc=s\&source=web\&c $\mathrm{d}=1 \& \mathrm{cad}=\mathrm{rja} \& u a c t=8 \& \mathrm{ved}=0 \mathrm{CCIQFjAAahUKEwj} 43 \mathrm{PykrJ} \_\mathrm{HAhUL}$ 6RQKHfgKAfs\&url=http $\% 3$ A\%2F\%2Feprints.lse.ac.uk\%2F54244\% 2F1\%2FMobile $\% 2520$ internet $\% 2520$ access $\% 2520$ and $\% 2520$ use $\% 25$ 20among\%2520European\%2520children_NCGM.pdf\&ei=aQjJVbiE LIvSU_iVhNgP\&usg=AFQjCNH2kdjkjc0pbg8iOe9PkCh0hvD81Q\& sig2=7hP0AKMBSkvi5Vv8CGraOQ\&bvm=bv.99804247,d.d24

[13] R. Viriyapong and A. Hartfield, "Facing the challenges of the One-Tablet-Per-Child policy in Thai primary school education," (IJACSA) International Journal of Advanced Computer Science and Applications, vol. 4, 2013.

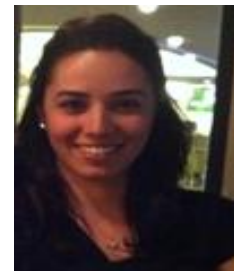

Tugba Mutlu was born in Turkey, in 1985. She received the B.A. degree in mathematics from Kafkas University, Turkey in 2007, the M.A. degree in mathematich teaching from Erciyes University, Turkey in 2008, and the M.Sc degree in information sciences from the University of Pittsburgh, USA in 2012.

She is currently a fourth year doctoral researcher at the University of Sheffield School of Education where she continues her research with funding from the Turkish Ministry of National Education. Her research interests lies primarily in the area of educational technology, technology acceptance, new digital technologies and digital literacy. Her $\mathrm{PhD}$ focuses on the technology acceptance behaviours of Turkish secondary school students towards using tablets for learning purposes. 